\title{
SELECTED ACUTE PHASE PROTEINS IN DAIRY COWS WITH CHRONIC DIARRHEA CAUSED BY MYCOBACTERIUM AVIUM SUBSP. PARATUBERCULOSIS
}

\author{
O. Nagy, Cs. Tóthová, P. Mudroň \\ onagy@uvm.sk
}

University of Veterinary Medicine and Pharmacy in Košice, Clinic of Ruminants, Komenského 68/73, Košice, 041 81, Slovak Republic

Paratuberculosis, or Johne's disease, is one of the most important intestinal chronic progressive granulomatous infections of ruminants with major economic impacts. The objective of this study was to evaluate the alterations in the concentrations of selected acute phase proteins in dairy cows with chronic diarrhea and seropositive to Mycobacterium avium subsp. paratuberculosis (MAP).

Blood samples from 44 dairy cows affected by chronic diarrhea were included into the study. The animals were seropositive for MAP antibodies, and showed obvious clinical signs of the disease (diarrhea, loss of body weight, general wasting). Nineteen clinically healthy and MAP negative cows were taken as a control group. Immunoenzymatic ruminant MAP-Ab test was used for specific detection of anti-Mycobacterium avium subsp. paratuberculosis antibodies in blood serum (Prionics Lelystad, The Netherlands). The concentrations of selected acute phase proteins - serum amyloid A (SAA), haptoglobin ( $\mathrm{Hp}$ ) and C-reactive protein $(C R P)$ were measured in blood serum. SAA was assessed by sandwich enzyme linked immunosorbent assay (ELISA) using commercial multispecies kits and haptoglobin was determined according to itsbiochemical activity to bind haemoglobin using commercial colorimetric kits (Tridelta Development, Ireland) in microplates. CRP was measured by solid-phase ELISA assay using commercially available tests (Life Diagnostics, Inc., USA).

The evaluation of the concentrations of SAA and Hp showed a trend of higher values in cows with diarrhea, however, the differences were statistically not significant. On the other hand, the concentrations of CRP were significantly higher in healthy animals compared with diarrheic cows $(P<0.001)$. These differences may be related to differences in the reactivity among several acute phase proteins, since Hp is characterized by more prolonged response. Thus, haptoglobin may be preferable in the field to evaluate disease processes, especially the course of chronic diseases. One of the reasons for lower concentrations of CRP in cows with chronic diarrhea may be its excessive loss through the gastrointestinal mucosa.

Because the pathogenesis of Mycobacterium avium subsp. paratuberculosis infection in cows and clinical manifestation of chronic diarrhea with subsequent protein-losing enteropathy has so far lacked knowledge of their impact on the changes of acute phase protein values, the results of the presented study represent significant widening of the knowledge in this area of research. They suggest a significant effect of chronic diarrhea in MAP seropisotive cows on the changes in the concentrations of some acute phase proteins.

\section{Keywords: COWS, DIARRHEA, PARATUBERCULOSIS, INFLAMMATION, PROTEINS}

Chronic diarrhea associated with malabsorption is less frequently documented in older or adult cattle, but represents a great problem on the affected farms causing high economic losses due to decreased milk production, higher risk of early culling, as well as decreased slaughter value [12, 17]. There are several pathogens that may cause chronic diarrhea in adult cattle. Paratuberculosis is one of the most important intestinal chronic progressive granulomatous infections of ruminants with major economic impacts [10]. The disease is caused by Mycobacterium avium subspecies paratuberculosis (MAP) through oral infection from forage, water, milk or environment contaminated with faeces containing bacteria from the infected animals [15]. The infection develops into granu- lomatous lymphadenitis, thickening and oedema of the intestinal mucosa resulting in intermittent treatment-resistant diarrhea $[2,14]$. The intestinal absorption of nutrients decreases consequently resulting in malabsorption associated with protein losing enteropathy, and in the advanced stages of the disease in decreased concentrations of blood proteins [16]. On the other site, the infection with MAP may be accompanied by immune and inflammatory reactions of the body, manifested also by the activation of macrophages, release of tumor necrosis factor alpha (TNF- $\alpha$ ) and other cytokines, as well as by increased production of acute phase proteins $[1,3]$. However, the mechanism of these reactions is not yet completely understood. Similarly, little is known about the effect of chronic 
diarrhea on the production of acute phase proteins in cows seropositive for MAP-antibodies (MAP$\mathrm{Ab})$. Therefore, this study was aimed to evaluate the concentrations of some acute phase proteins in chronic diarrhea associated with paratuberculosis in dairy cows seropositive for MAP-antibodies.

\section{Materials and methods}

Blood samples from 44 dairy cows affected by chronic diarrhea manifesting for more than two weeks were included into this study. The sampled animals were of a low land black spotted breed, Slovak spotted breed and their crossbreeds at the age of 3.5 to 8 years, and were from four conventional dairy farms with similar feeding and management regimes, and occurence of Mycobacterium avium subspecies paratuberculosis (MAP) infections in the herd. The evaluated cows were positive for MAP-antibodies. All of these animals showed clinical signs of the disease, characterised by persistent diarrhea, reduced milk yield, loss of body weight, and general muscle wasting. 19 clinically healthy MAP-negative cows without any signs of diseases and in good general condition were selected as control animals. Blood samples were taken from these animals from $v$. jugularis into serum gel separator tubes without any additives or anticoagulants (Meus, Piove di Sacco, Italy). Blood samples were centrifuged at $3000 \mathrm{~g}$ for $20 \mathrm{~min}$. The harvested serum was dispensed into plastic tubes, and stored at $-20{ }^{\circ} \mathrm{C}$ until it was analysed.

Immunoenzymatic ruminant MAP-Ab test was used for specific detection of anti-Mycobacterium avium ssp. paratuberculosis antibodies in blood serum (Prionics Lelystad, The Netherlands). To evaluate the changes in selected acute phase proteins the serum concentrations of serum amyloid A(SAA, $\mu \mathrm{g} / \mathrm{ml})$, haptoglobin ( $\mathrm{Hp}, \mathrm{mg} / \mathrm{ml}$ ) and $\mathrm{C}$-reactive protein $(\mathrm{CRP}, \mu \mathrm{g} / \mathrm{ml})$ were evaluated. SAA was assessed by sandwich enzyme linked immunosorbent assay (ELISA) using commercial multispecies kits (Tridelta Developmet, Ireland). Haptoglobin was determined according to its biochemical activity to bind haemoglobin using commercial colorimetric kits (Tridelta Development, Ireland) in microplates. CRP was measured by solid-phase ELISA assay using commercially available tests (Life Diagnostics, Inc., USA). The absorbancies were read on automatic microplate reader Opsys MR and the results were calculated using the computer software Revelation QuickLink version 4.25 (Dynex Technologies, USA).

The statistical analyses were done with the programme GraphPad Prism V5.02 (GraphPad Software Inc., California, USA). Descriptive statistical procedures were used to calculate arithmetic means (x) and standard deviations (SD) for each evaluated variable and group of animals. The significance of differences in values between cows with chronic diarrhea and healthy animals, as well as between highly and weaker MAP-positive cows was examined by unpaired $t$-test.

\section{Results and discussions}

The data obtained in healthy and sick cows are presented in table and fig. The evaluation of the concentrations of SAA and Hp showed a trend of higher values in cows with diarrhea, however, the differences were statistically not significant. On the other hand, the concentrations of CRP were significantly higher in healthy animals compared with diarrheic cows $(\mathrm{P}<0.001)$. While the concentrations of SAA were approximately 1.7-fold higher in diarrhoic cows compared with healthy ones, the values of Hp were about 2.9-fold higher in sick animals.

Differences in the concentrations of SAA, Hp and CRP between cows with chronic diarrhea and clinically healthy cows $($ mean \pm SD)

\begin{tabular}{|l|c|c|c|}
\hline \multirow{2}{*}{ Variables } & \multicolumn{2}{|c|}{ Groups of cows } & \multirow{2}{*}{$\begin{array}{c}\text { P } \\
\text { value }\end{array}$} \\
\cline { 2 - 3 } & $\begin{array}{c}\text { Chronic diarrhea } \\
(\mathrm{n}=44)\end{array}$ & $\begin{array}{c}\text { Healthy } \\
(\mathrm{n}=19)\end{array}$ & n.s. \\
\hline $\mathrm{SAA}, \mu \mathrm{g} / \mathrm{ml}$ & $27.44 \pm 45.51$ & $15.69 \pm 11.85$ & n.s. \\
\hline $\mathrm{Hp}, \mathrm{mg} / \mathrm{ml}$ & $0.238 \pm 0.374$ & $0.080 \pm 0.020$ & n.s \\
\hline $\mathrm{CRP}, \mu \mathrm{g} / \mathrm{ml}$ & $45.45 \pm 61.65$ & $150.10 \pm 72.80$ & $<0.001$ \\
\hline
\end{tabular}

Note: P value - significance of the unpaired $t$-test, n.s. - not significant.

The differences in the rate of increase of SAA and Hp may be related to differences in the reactivity among several acute phase proteins, since $\mathrm{Hp}$ is characterized by more prolonged response. Thus, haptoglobin may be preferable in the field to evaluate disease processes, especially the course of chronic diseases. The behavior of CRP in cattle affected by chronic diarrhea associated with proteinlosing was not yet described. One of the reasons 
for lower concentrations of CRP in cows with chronic diarrhea may be its excessive loss through the gastrointestinal mucosa.

[7] found an increase of the concentrations of haptoglobin (by $26 \%$ ) and serum amyloid A (by $37 \%$ ) in cattle infected with Mycobacterium bovis. Furthermore, they determined a good prognosis for animals with $\mathrm{Hp}$ values between 0.1 and $1.0 \mathrm{~g} / \mathrm{l}$. The increase of SAA and Hp might be related to the tissue damage caused by the bacteria. Increased $\mathrm{Hp}$ and SAA concentrations were observed also in our study in cows seropositive for MAP-antibodies clinically manifested by chronic diarrhea due to severe inflammatory changes in the intestinal wall. While the concentrations of SAA were approximately 1.7-fold higher in diarrhoic cows compared
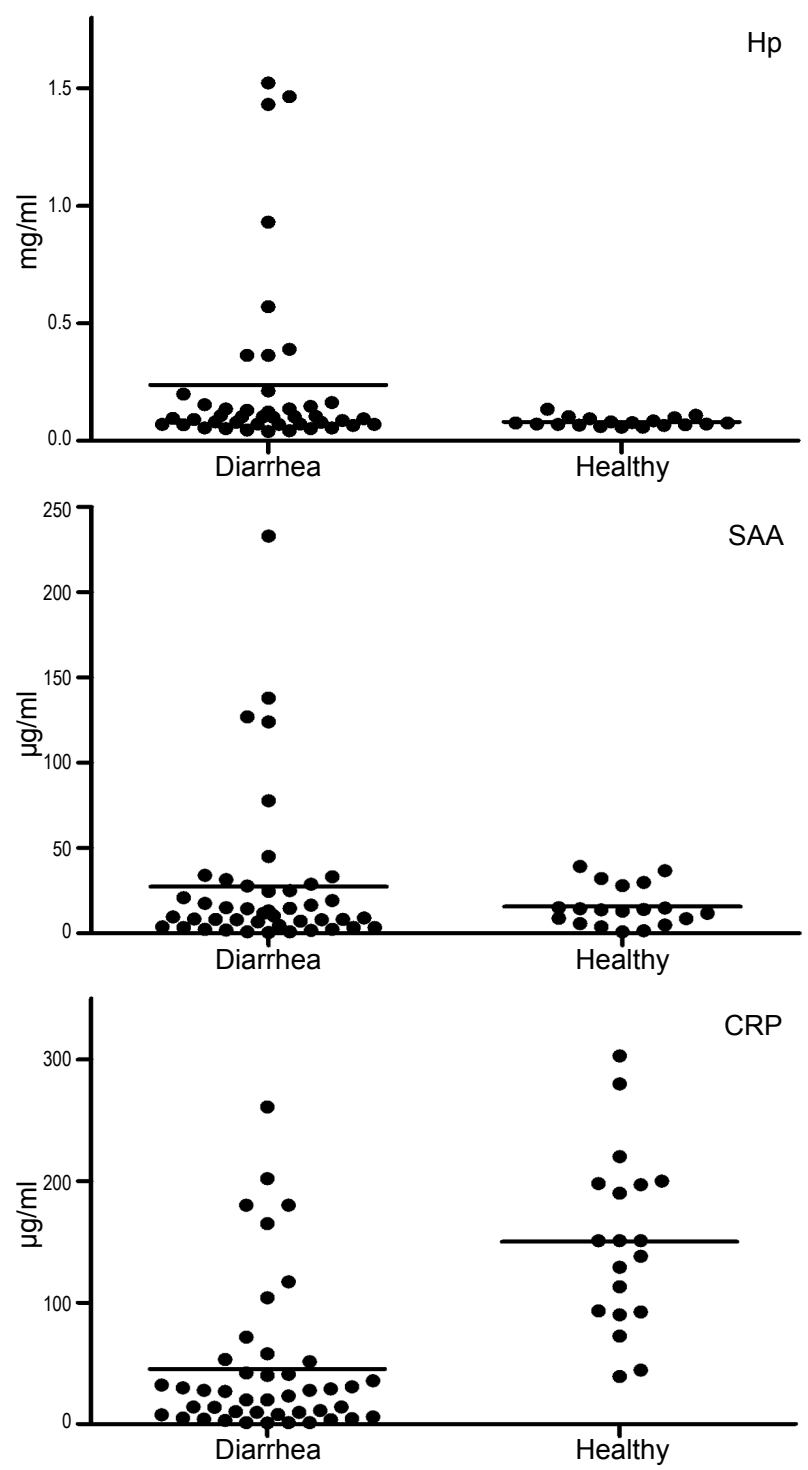

Fig. Distribution of individual values of analyzed acute phase proteins in cows with diarrhea and clinically healthy cows with healthy ones, the values of Hp were about 2.9fold higher in sick animals. These differences in the rate of increase may be related to differences in the reactivity among several acute phase proteins, since $\mathrm{Hp}$ is characterized by more prolonged response. Thus, haptoglobin may be preferable in the field to evaluate disease processes, especially the course of chronic diseases [9]. The wider range of measured concentrations and higher values of standard deviations suggest that there are great differences in the reactivity of animals to respond to various inflammatory stimuli. Different disease severity might be another reason for wider range of values, i.e. more severe disease processes are accompanied by higher concentrations of acute phase proteins [6]. Elevated concentrations of SAA were found also in patients with inflammatory bowel disease associated with active gut inflammation and in mice exposed to Mycobacterium avium subsp. paratuberculosis manifested with colitis and weight loss $[4,11]$. In ruminants, CRP it is a constitutively synthesised protein, with only a minor increase during disease processes [5]. In the present study, the concentrations of CRP were lower in cows with chronic diarrhea compared with clinically healthy animals. The behavior of CRP in cattle affected by chronic diarrhea associated with protein-losing was not yet described. One of the reasons for lower concentrations of CRP in cows with chronic diarrhea may be its excessive loss through the gastrointestinal mucosa, similarly to typically elevated fecal loss of $\alpha_{1}$-antitrypsin in human patients, as well as in dogs suffering from protein-losing enteropathy $[8,13]$. However, further studies are needed to evaluate the usefulness of CRP in the differential diagnosis of chronic diarrhea in cattle associated with various degree of hypoproteinemia.

\section{Conclusions}

Because the pathogenesis of Mycobacterium avium subsp. paratuberculosis infection in cows and clinical manifestation of chronic diarrhea with subsequent protein-losing enteropathy has so far lacked knowledge of their impact on the changes of acute phase protein values, the results of the presented study represent significant widening of the knowledge in this area of research. They suggest an effect of chronic diarrhea in cows seropositive for 
paratuberculosis on changes in the concentrations of the evaluated acute phase proteins. The differences in the rate of increase of SAA and Hp may be related to differences in their reactivity and haptoglobin may be preferable in the field to evaluate disease processes, especially the course of chronic diseases. The behavior of CRP in cattle affected by chronic diarrhea associated with protein-losing was not yet described. One of the reasons for lower concentrations of CRP in cows with chronic diarrhea may be its excessive loss through the gastrointestinal mucosa. However, further investigations are needed to establish the diagnostic accuracy of serum protein protein electrophoresis in the differential diagnosis of chronic diarrhea in cattle.

Acknowledgements. This work was supported by Scientific Grant Agency of Ministry of Education SR No. 1/0486/17 and 1/0398/18.

1. Buza J. J., Mori Y., Bari A. M., Aodon-geril H. H., Hirayama S., Shu Y., Momotani E. Mycobacterium avium subsp. paratuberculosis infection causes suppression of RANTES, monocyte chemoattractant protein 1 , and tumor necrosis alpha expression in peripheral blood of experimentally infected cattle. Infection and Immunity, 2003, vol. 71, issue 12, pp. 7223-7227. DOI: 10.1128/ IAI.71.12.7223-7227.2003.

2. Clarke C. J. The pathology and pathogenesis of paratuberculosis in ruminants and other species. Journal of Comparative Pathology, 1997, vol. 116, issue 3, pp. 217-261. DOI: 10.1016/S0021-9975(97)80001-1.

3. Coussens P.M. Model for immune responses to Mycobacterium avium subspecies paratuberculosis in cattle. Infection and Immunity, 2004, vol. 72, issue 6, pp. 3089-3096. DOI: 10.1128/IAI.72.6.3089-3096.2004.

4. De Beer F.C., Fagan E. A., Hughes G. R., Mallya R. K., Lanham J. G., Pepys M. B. Serum amyloid-A protein concentration in inflammatory diseases and its relationship to the incidence of reactive systemic amyloidosis. The Lancet, 1982, vol. 320, issue 8292, pp. 231-234. DOI: 10.1016/S0140-6736(82)90321-X.

5. Eckersall P. D. Proteins, proteomics, and the dysproteinemias. In: Kaneko J. J., Harvey J. W., Bruss M. L. Clinical biochemistry of domestic animals. $6^{\text {th }}$ ed. California, Elsevier Academic Press, 2008, pp. 117-155. DOI: 10.1016/B978-0-12-370491-7.00005-2.

6. Lomborg S. R., Nielsen L. R., Heegaard P. M. H., Jacobsen S. Acute phase proteins in cattle after exposure to complex stress. Veterinary Research Communications, 2008, vol. 32, issue 7, pp. 575-582. DOI: $10.1007 / \mathrm{s} 11259-008-9057-7$.
7. Merhan O., Bozukluhan K., Çelebi Ö., Öğün M., Atakişi E., Büyük F. Levels of acute phase protein and some biochemical parameter in cattle infected with Mycobacterium bovis. Journal of Faculty of Veterinary Medicine, Erciyes University, 2017, vol. 14, issue 2, pp. 101-105.

8. Murphy K. F., German A. J., Ruaux C. G., Steiner J. M., Williams D. A., Hall E. J. Fecal alpha-1 protease inhibitor concentration in dogs with chronic gastrointestinal disease. Veterinary Clinical Pathology, 2003, vol. 32, issue 2, pp. 67-72. DOI: 10.1111/j.1939165X.2003.tb00316.x.

9. Petersen H. H., Nielsen J. P, Heegaard P. M. H. Application of acute phase protein measurements in veterinary clinical chemistry. Veterinary Research, 2004, vol. 35, issue 2, pp. 163-187. DOI: 10.1051/ vetres:2004002.

10. Pillars R. B., Grooms D. L., Wolf C. A., Kaneene J. B. Economic evaluation of Johne's disease control programs implemented on six Michigan dairy farms. Preventive Veterinary Medicine, 2009, vol. 90, issue 3-4, pp. 223-232. DOI: 10.1016/j.prevetmed.2009.04.009.

11. Singh U. P., Singh S., Singh R., Karls R. K., Quinn F. D., Potter M. E., Lillard J. W. Jr.Influence of Mycobacterium avium subsp. paratuberculosis on colitis development and specific immune responses during disease. Infection and Immunity, 2007, vol. 75, issue 8, pp. 3722-3728. DOI: 10.1128/IAI.01770-06.

12. Smith R. L., Grohn Y. T., Pradhan A. K., Whitlock R. H., Kessel Van J. S., Smith J. M., Wolfgang D. R., Schukken Y. H. A longitudinal study on the impact of John's disease status on milk production in individual cows. Journal of Dairy Science, 2009, vol. 92, issue 6, pp. 2653-2661. DOI: $10.3168 / \mathrm{jds} .2008-1832$.

13. Strygler B., Nicar M. J., Santangelo W. C., Porter J. L., Fordtran J. S. Alpha 1-antitrypsin excretion in stool in normal subjects and in patients with gastrointestinal disorders. Gastroenterology, 1990, vol. 99, issue 5, pp. 1380-1387. DOI: 10.1016/0016-5085(90)91165-3.

14. Sweeney R. W. Transmission of paratuberculosis. Veterinary Clinics of North America: Food Animal Practice, 1996, vol. 12, issue 2, pp. 305-312. DOI: 10.1016/S0749-0720(15)30408-4.

15. Sweeney R. W., Whitlock R. H., Rosenburg A. E. Mycobacterium paratuberculosis isolated from fetuses of infected cows not manifesting signs of disease. American Journal of Veterinary Research, 1992, vol. 53, issue 4, pp. 477-480.

16. Tiwari A., VanLeeuwen J. A., McKenna L. B., Keefe G. P., Barkema H. W. Johne's disease in Canada Part I: clinical symptoms, pathophysiology, diagnosis, and prevalence in dairy herds. The Canadian Veterinary Journal, 2006, vol. 47, issue 9, pp. 874-882.

17. Wittek T. Overview of malassimilation syndromes in large animals. In: Aiello S. E., Moses M. A. The Merck Veterinary Manual. $11^{\text {th }}$ ed. Kenilworth, Merck \& Co. Inc., 2016, pp. 353-360. 